\title{
Historein
}

Vol 12 (2012)

Questions and Orientations in History during the last 20 years. Part 1

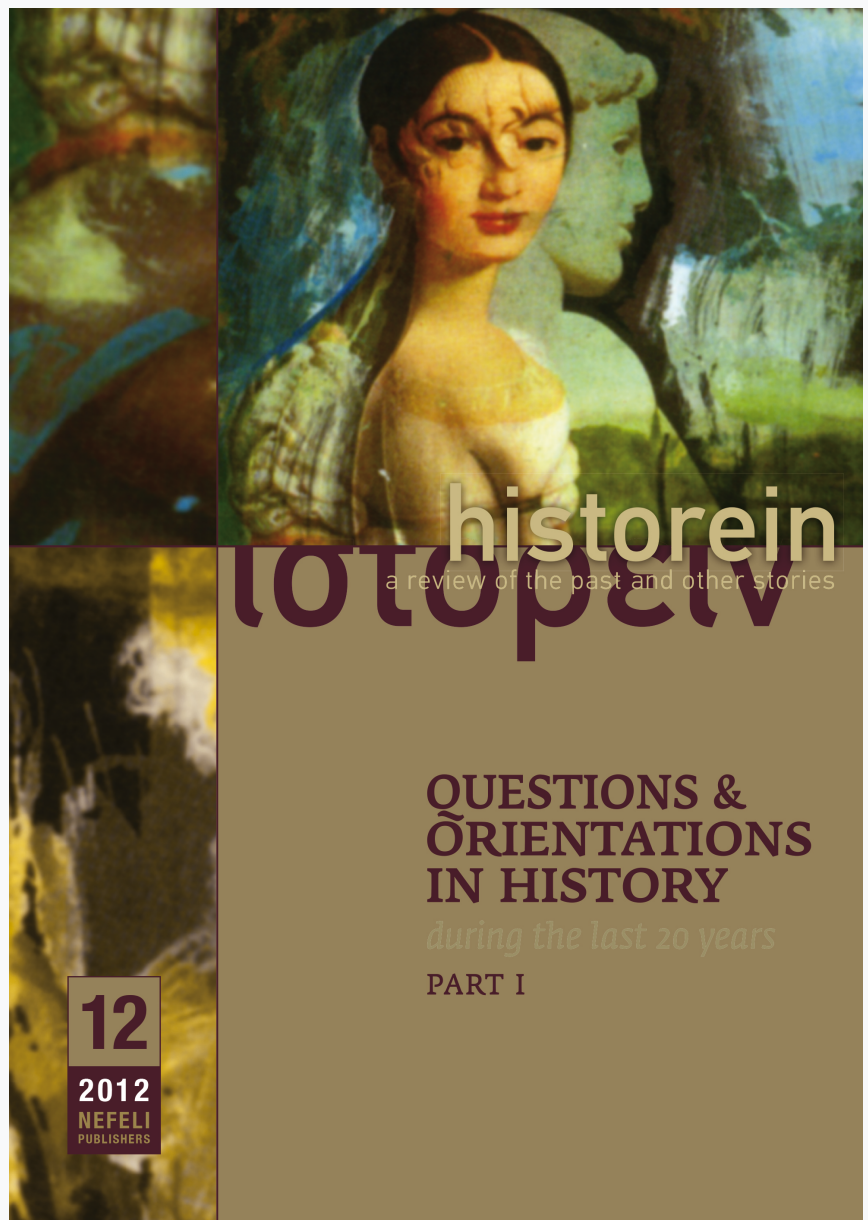

\section{Archaeology after the End of history}

Dimitris Plantzos

doi: $10.12681 /$ historein.154

Copyright $\odot$ 2013, Dimitris Plantzos

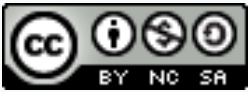

This work is licensed under a Creative Commons Attribution-NonCommercialShareAlike 4.0.

\section{To cite this article:}

Plantzos, D. (2013). Archaeology after the End of history. Historein, 12, 68-78. https://doi.org/10.12681/historein.154 


\section{Archaeology after the End of History}

Dimitris Plantzos

University of Athens
In 1988, just as Francis Fukuyama was beginning to wonder whether in fact mankind was reaching "the end of history" (an idea he first broadcast, tentatively, in the summer of 1989), a cartoon by Simon James, illustrating "archaeological theory in 1988”, was circulating among British archaeologists (Fig. 1). ${ }^{2}$ The drawing shows a bunch of angry theorists going at each other ("processualist reactionary!", "post-processualist pseud!", "phallocrat scum-bag" and so on), while only an elderly classical archaeologist, duly suited, bearded and piped, is happy reading his pocket Loebs and cumbersome volumes of the Corpus Inscriptionum Latinarum. Bewildered by the fracas, your typical Joe Public family are standing by, only to be greeted with contempt by one of the enraged archaeologists ("What the hell do you want?"). And that was at about the same time when Mr Public, his family and their friends were crowding cinemas around the world to enjoy the third instalment in the Indiana Jones film serial - Steven Spielberg's Indiana Jones and the Last Crusade (1989). Placed in the 1930s, the movie contains one of the most famous aphorisms about archaeology ever made on film: as soon as he is back from yet another adventure overseas, and literally minutes before the quest for nothing less but the Holy Grail itself takes him round the world once again, Prof. Henry Walton Jones Jr finds the time to teach a class, where he informs his flabbergasted students: "Archaeology is the search for fact; not truth. If it's truth you're interested in, Dr Tyree's philosophy class is right down the hall." Needless to say, Dr Tyree is never given the chance to present his case in the movie, and although Prof. Indy mutters something about how "70 percent of all archaeology is done in the library" and that "we cannot afford to take mythology at face value", we can be cer- 
tain that he, as a seasoned archaeologist and a man of the world, knows that his job is to do rather than to think. And that's that.

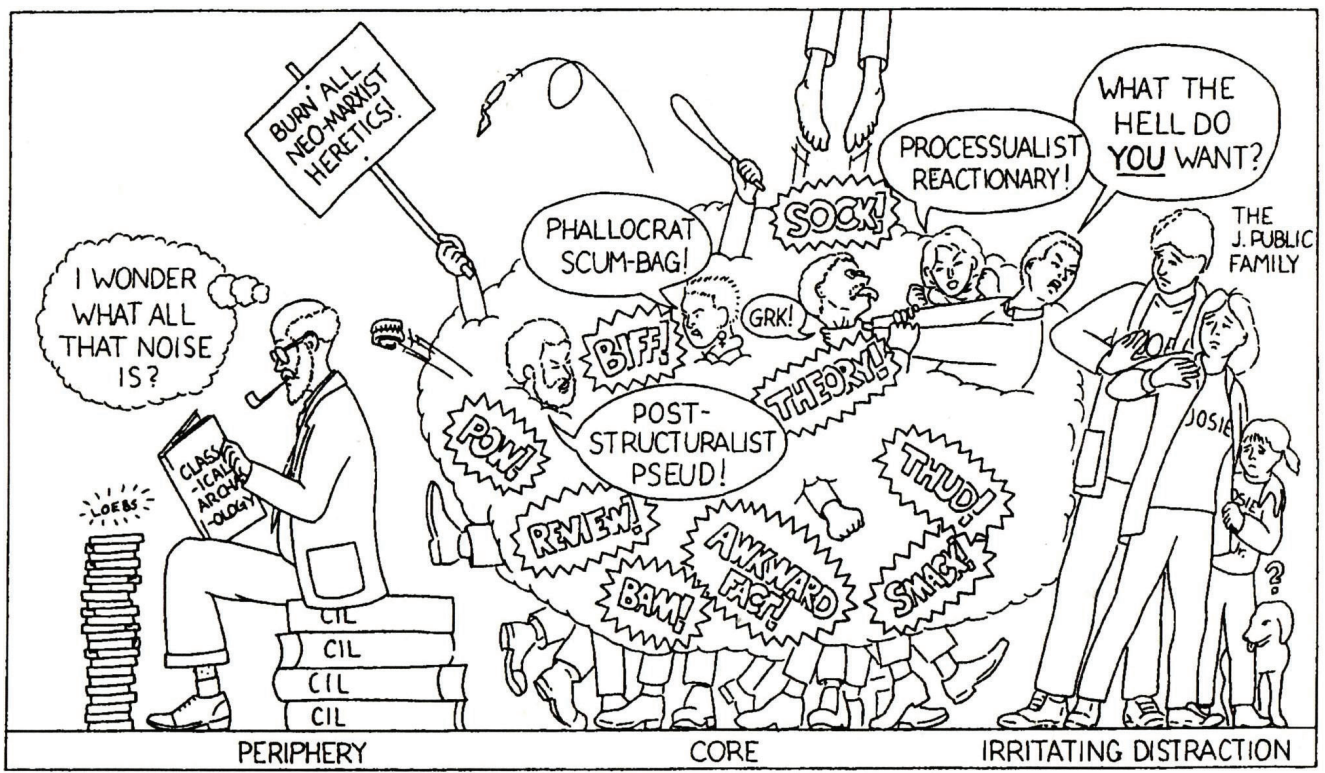

Fig. 1. Archaeological theory in 1988. (C) Simon James

I have a feeling that Francis Fukuyama would applaud Indy's crass statements. His strong conviction of the final "triumph of the West", a triumph "evident first of all in the total exhaustion of viable systematic alternatives to Western liberalism", ${ }^{3}$ led him, we all know, to the publication, in 1992, of one of the most-quoted (albeit least-read!) books of the twentieth century, The End of History and the Last Man. There, he claimed that the universalisation of western liberal democracy that seemed imminent after the end of the cold war and the dissolution of the Soviet Union, would signify the end of mankind's ideological evolution. New challenges were doubtless expected to rise - such as Islamism, or the refusal of some third-world fundamentalists to abandon their old nationalist ways - but the west was destined to triumph in the end, based on its ethical and political superiority, pretty much like Indiana Jones himself (allowing of course for his sexy grin and unbeatable sense of humour). In a way, Fukuyama was fantasising about a Marxist utopia in reverse; and that was that.

So what are archaeologists so mad about in Simon James' cartoon? Don't they have classes to teach? Digs to attend to? Holy quests to pursue? Whereas Fukuyama's book and Spielberg's film, though entirely unrelated to one another, succeed in pushing their elitist, liberal, racist and sexist agenda based on strongly deterministic readings of history and their even stronger westernsupremacist convictions, the cartoon turns, as it were, to "the smaller picture". The thing is, while history was ending in the mid- to late-1980s, archaeology was busy dealing with what to many 
looked like new beginnings. James is right to comment on archaeology's estrangement from the general public (a fact cinema took huge advantage of), even though his academic upbringing compels him to generate some elitism of his own. The crisis evident in James' cartoon signifies archaeology's mass exodus to theory, a traumatic event for many of its protagonists (and certainly their students), a process that has led to the archaeologies of today. Already by the late 1990s, another archaeologist was to provide a quite different picture (Fig. 2): clusters of archaeological theorists are seen conversing in a quite civilised (though admirably nonarchaeological!) way: "Foucault and feminism", "Darwin", "sex for food" and so on, while good old classical archaeologist is still happy with his heavy tomes and the Publics are gone "to the real world" for good. ${ }^{4}$

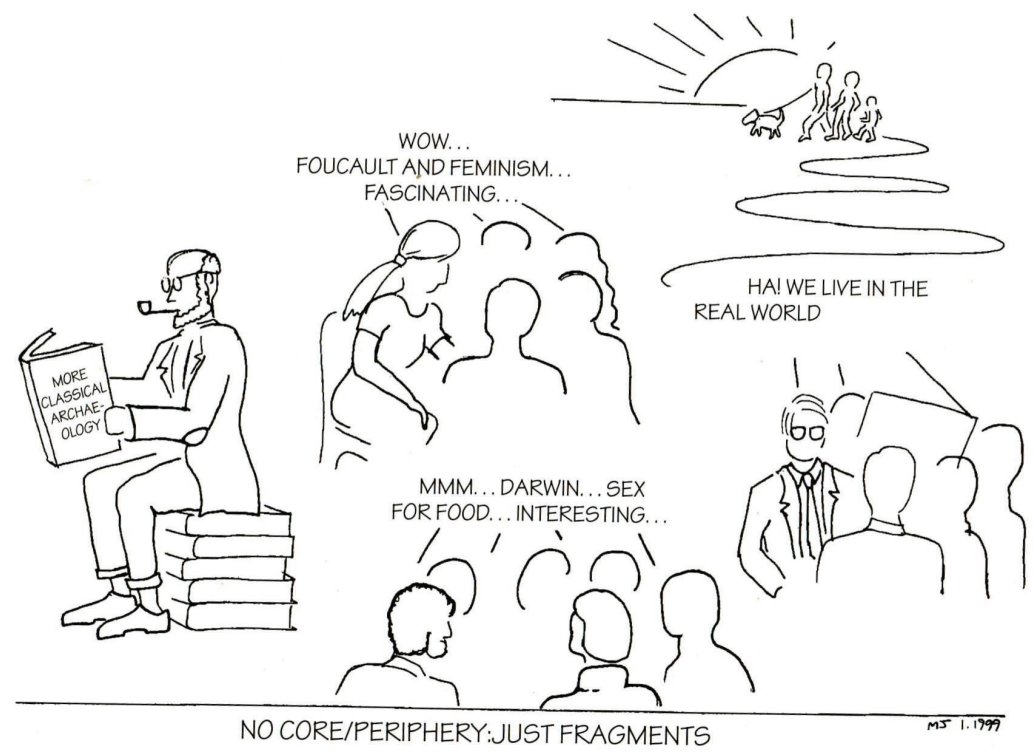

Fig. 2. Archaeological theory in 1998. (c) Matthew Johnson

\section{Archaeology and theory: a contradiction in terms?}

Indiana Jones was right when he was advocating a nontheoretical archaeology in the mid-1930s (or the late-1980s for that matter). For the most part, archaeology is considered an artefact-based episteme, a positivistic, scientific account of the past on the basis of its material remains. Antiquarianism, archaeology's childhood so to speak, encouraged collecting, cataloguing and endless classification - some of archaeology's most endearing traits to the present day - thus leading to a quasifetishist attachment to the artefact. Objects, as bearers of self-evident truths, were what archaeologists were after worldwide, especially in the west, where the obsession with origins was an inherent affectation of modernity. Nationalism and colonialism, the two principal political projects through which the west attempted - and to a great extent succeeded - first to explain and then to contain the world at large, employed archaeology as a means by which to forge essentialist en- 
tities and primordial genealogies at home and abroad. To that end, the museum was deployed in and out of the west as a disciplinary tool, an apparatus for control and surveillance. ${ }^{5}$ In effect, archaeology as a civilising mission on the one hand and the care for antiquities as an index of modernisation on the other were exported to the non-west in the framework of a widespread westernisation process. ${ }^{6}$ It is therefore not quite accidental that archaeology, even in its most progressive reincarnations, assumes an elitist, patriarchal poise: as an allochronic discourse, studying "other" peoples and their cultures, archaeology has developed an expertise in studying a people's past as a way of colonising that people's social imaginary, in effect constructing the Other as an artefact, and an archaeological one at that. ${ }^{7}$

Dissatisfied with the empiricist and normative discourses dominating archaeological theory and practice until then, a bunch of young Anglo-American theorists of the 1960s and early 1970s launched what they styled as "new archaeology", a loose set of epistemological rules and axioms attempting to turn their discipline towards a direction that was at once more scientific and more anthropological. ${ }^{8}$ In that they were following similar trends already developing elsewhere, such as "new geography", "new social history", etc. Declaring archaeology's "loss of innocence", new archaeologists pushed for a militant agenda ostensibly bound to guarantee scientific accuracy and historical objectivity. Their approach was systemic (placed an emphasis on culture as a system of beliefs, practices, and ideas evolving through time) and processual (focusing on the historical processes that created the artefacts at hand rather than the artefacts in themselves); in many ways they seemed to share the approach of the Annales school, an affinity some new archaeologists denied and others were to cultivate further in the decades to come. In an attempt to sanitise archaeology from any anthropocentric, idealist or empiricist bias, new archaeologists described culture as "man's extrasomatic means of adaptation", ${ }^{10}$ and its development as a "dynamic equilibrium between the subsystem networks of a single socio-cultural system and its total environmental system" (Fig. 3)."

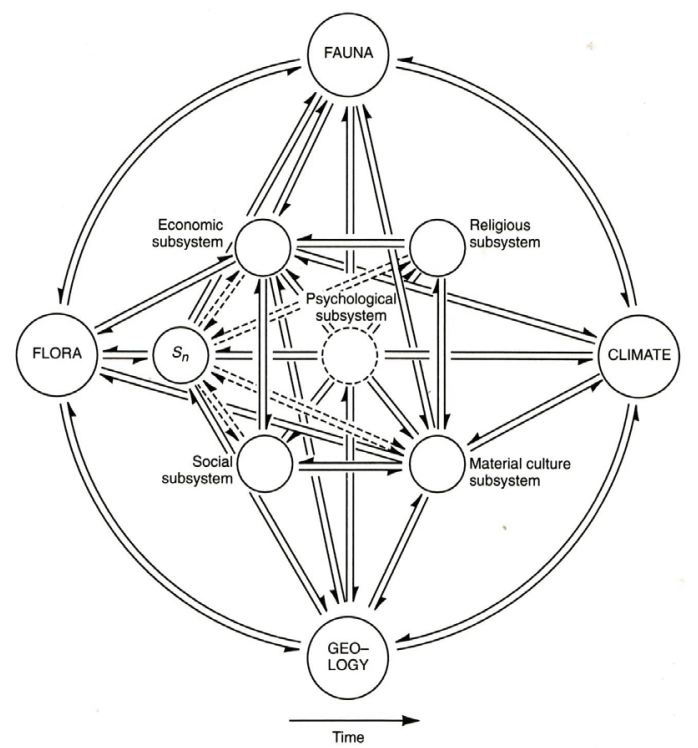

Fig. 3. Culture as a system. (C) David Clarke 
By the mid-1980s, such a sterilised approach to human cultures, past and present, appeared to be frightfully out of date, and the ensuing debate - quite fierce, if we are to believe Simon James and the cartoon in Fig. 1 - attempted to put things in new perspectives. lan Hodder's Reading the Past, first published in 1986, ${ }^{12}$ was put forward as archaeology's renewed bid "to recapture its traditional links with history". ${ }^{13}$ Convinced that culture may not be interpreted by means of a functionalist/systemic model, Hodder argued for a reconsideration of human agency as a historical factor, suggesting that rather than mere reaction to the environmental system, culture is creation. Influenced by structuralism, semiotics, anthropology and sociology (especially Bourdieu's views on agency and social structure) and earlier authorities such as R.G. Collinwood, Hodder outlined a new, postprocessual method assuming three basic principles: that cultures - past or present - are textual, that is bearers of meanings, ideas and sentiments; that the individual acts as a historical agent within any given cultural system rather than being merely subject to a predetermined structure; and, more to the point, that archaeology's task is to interpret the past rather than describe its material remains.

Abandoning positivism had a significant influence on archaeological thinking. The idea that as archaeologists we are not meant merely to describe, classify and catalogue the material remains of past cultures, but instead to study the historical circumstances that led to their depositing, appeared to throw traditional archaeological thinking out of balance. An influx of new ideas - mostly borrowed from poststructuralist linguistics, sociology, social anthropology and literary criticism - encouraged the emergence of countless new trends, branches and "-isms" of greater or lesser importance. Cognitive and behavioural archaeology became two such significant strands applying postprocessual methodology, whereas others, such as the archaeology of gender, promoted different lines of inquiry, of "low historicity" so to speak, enabling contextual studies in ways neither the traditional nor the systemic/positivist schools were able or even willing to pursue. Contextuality for many, and especially those hardcore processualists still alive and kicking, meant relativism, a charge that in the 1980s could be as formidable as charlatanism. Modernist and neo-Marxist reactions against postmodern ideas (in Oxbridge that amounted to denouncing anything French) targeted poststructuralist approaches to archaeology as unscientific, as they seemed to forgo any pretentions of universal theories or verification protocols. Even Hodder himself was by 1992 assuring everyone who cared to listen that he "did not want to go all the way down the road of value-commitment and political motivation"; neither did he "want to accept a deconstructionist approach and the open play of meaning". ${ }^{14}$

\section{Archaeological context: it's not text, stupid!}

When postprocessualists refer to archaeological context, what they actually have in mind is text. As Hodder put it back in 1986: "most archaeological objects are ... situated in place and time and in relation to other archaeological objects. This network of relationships can be 'read', by careful analysis ... in order to reach an interpretation of meaning content."15 This view privileges a culture's textual qualities (as opposed to the tactility, materialilty and other sensory or in any way nontextual qualities of its material remains), as well as the archaeologist's intellect, against the artefacts and the peoples under assessment. More to the point, it promises a traditional kind of quasiscientific 
discourse based on the apparent neutrality of the text and the presumed impartiality of its reader; in a sense, we are still dealing with archaeology as an allochronic episteme.

As it happens, poststructuralist linguistics, and deconstruction in particular, managed at long last to shake our confidence in the text - written, oral, cultural or other - at the same time depriving philology from its erstwhile privileges as modernity's main foundation pillar. Jacques Derrida was never very popular with archaeologists, who seemed unable to grasp his counter-rationalist, deeply subversive ideas. For many, the application of deconstructive methodology in archaeology would lead to "the past as play and pastiche, the past as wished for". ${ }^{16}$ Whereas postprocessual methodology is often cast as the postmodern counterpart to processual archaeology as its modernist predecessor, there is nothing really postmodern about the way postprocessualists think or write. Postprocessual archaeology (to the extent one can refer to it as a homogenous subdiscipline) is as much about universal theories and systems of measurement as new archaeology ever was; objectivity and verification, as well as the conviction that archaeologists are external to the histories they study, remain its trademarks and constituent beliefs. If truth be told, one would have to move beyond the processual/postprocessual divide in order to find archaeological theory significantly influenced by postmodern thinking. Roland Barthes, Michel Foucault, Julia Kristeva and Derrida himself have exercised some considerable influence on several aspects of archaeological work in the last 20 years or so, and especially its branches dealing with aspects of social life such as politics, gender and so on. The Foucauldian notion of power for one, as a diffused, embodied and enacted regime of truth pervading society, has greatly informed discussions, often heated, on classical Greece and Rome - territories usually left unexplored by both the new archaeologists and their postprocessual successors. ${ }^{17}$ Even the much-loathed "relativism" has been part and parcel of certain branches of archaeological thinking since as early as the 1990s, based on Derridean and Barthean semiotics as well as a somewhat less cavalier reading of deconstructionism: "Our activities as archaeologists consist in dismantling an object (the past, material culture) and reconstructing a simulacrum of it in our meta-language," said Bjørnar Olsen in 1990, when discussing the ways writing serves the a posteriori ideological construction of the past. ${ }^{18}$

Theorising culture as neither system nor text, however, asks for a different sort of academic reasoning, open to relativism and committed to interdisciplinarity. This would entail abandoning archaeolo-

gy's inherent idealism - be that of the scientist or the humanist kind. While hardcore processualists still debate "the importance of the 'individual' in the creation of the archaeological record", ${ }^{19}$ social studies - and social anthropology in particular - provide theoretical paradigms which do not subscribe to traditional history's teleological, linear narratives; more to the point, these narratives by definition involve questions of cultural interaction and reception, while at the same time focusing on the role of the archaeologist as an agent of cultural sensibility, information and bias.

\section{'Going all the way': art, agency, materiality}

As archaeologists we traditionally deal with objects; this however has not made us any better in understanding their materiality. Rooted in the Enlightenment, and the humanist tradition at large, 
archaeology assumes a number of given polarities in its study of the physical world, and takes them for granted in its epistemology: human vs. artefact, real vs. ideal, textual vs. visual and so on. All these pairs express a deeper dichotomy in the way mainstream western thought comprehends and classifies the world: subject vs. object, present vs. past, praxis vs. theory. As a result, even though archaeology is supposed to study objects, it does so through a sociocultural understanding that describes them only as somebody's - a human person's - creations, possessions, tools, weapons or, ultimately, garbage. At its worse, this tendency personifies nonhuman entities such as states or regimes, so that objects can be attributed once again to "living" cities, religions or empires, and of course, cultures. And when it comes to "art" - any form of artefact, really, with even the slightest suggestion of decorative intent on behalf of its maker or nonpractical use on behalf of its owner - archaeologists either turn to art historians and connoisseurs or pretend not to notice what they are actually dealing with.

Since the 1990s, however, certain developments in the social sciences have encouraged archaeologists to rethink the way they configure the material world. Theorists like Bruno Latour initiated an attempt to understand ways in which materials influence the life and thinking of people irrespective of human agency. In his effort to "reassemble the social", Latour argued that "any thing that does modify a state of affairs by making a difference is an actor" and that certainly includes nonhuman objects, which are "nowhere to be said and everywhere to be felt". ${ }^{20}$ Actor-NetworkTheory, a collective approach to sociology of which Latour was a cofounder, started as an attempt to chart innovation and knowledge-production as scientific processes. To that end, it returned to earlier concepts such as phenomenology - in Phenomenology of Spirit, written in 1807, Hegel insisted that there is no fundamental division between the human and the material - in order to avoid the essentialism of modern science. Rather than as mere bearers of social structures and meanings, therefore, nonhuman entities are considered as active agents within the social networks: "Is not society built literally - not metaphorically - of gods, machines, sciences, arts and styles?" Latour was asking already in 1991.21

"Styles" of course means art, and art - from the Venus de Milo (or the Venus of Willendorf for that matter) to Rurutan A'a figurines, Marquesan weapons and Pechanga basketry - is what archaeologists claim to know best. Materiality was hesitantly introduced to archaeology in the last ten years or so, and this has often produced rather awkward results, especially when it looked like an alien idea forced into a pre-existing system of thought. Eventually, however, archaeologists are realising they "have to move beyond the representational economy". ${ }^{22}$ What this entails is not quite understood yet; however, this new representational economy would have to involve less of archaeology's traditional materialism (also evident in new archaeology) as well as its inherent humanism (mostly indulged in by classical archaeology, of course, but also central in postprocessualism). Incidentally, though not necessarily, this enmeshment of the human with the nonhuman in sociocultural terms would reflect most of the ancient cultures we study, that is the ways these cultures viewed artefacts as independent agents rather than intermediaries between human ideas, sentiments or wills.

Latour was right to talk of nonhuman agency, an idea adopted by many theorists of visual culture, like W.J.T. Mitchell who emphatically asked himself and his readership "What do pictures want?", in an effort to comprehend the "appetites, needs, demands, drives" that pictures seek to satisfy in 
their confrontation with us humans. ${ }^{23}$ Directly or indirectly, any attempt to understand agency in cultural artefacts draws its inspiration from Alfred Gell's pioneering work in the mid-1990s. In his Art and Agency, published posthumously, Gell identified "art" as neither an aesthetic nor a quasilinguistic phenomenon, thus excluding both connoisseurship and semiotics from the study of cultural artefacts. ${ }^{24}$ For some time, like with materiality, agency was yet another awkward term for archaeologists, an inevitable yet impossible strategic choice, since it entailed abandoning some of their discipline's most treasured methodologies (such as stylistic studies and their semiotics). As archaeology was becoming more anthropological, however, the concept of agency, both as a counterpart to materiality and on its own, has enabled archaeologists to refine their understanding of cultural relationships, thus moving away from an essentialist/humanist agenda. Concepts of agency have greatly, and refreshingly, influenced also our understanding of landscapes, hitherto accepted as lived-in containers of human activity, though now seen to possess "their own unique qualities and competences which they bring to our cohabitation with them". 25

\section{Archaeology and postcoloniality}

"In the modern world the past is a commodity of mixed value," said John Boardman in the preface to his 2002 book The Archaeology of Nostalgia. ${ }^{26}$ As a matter of fact, this could have also been his conclusion, as since the 1990s we are becoming increasingly aware of the active roles the past plays in our present, and the ways societies define themselves on the basis of a collective past they actively imagine, enhance and promote. For the most part, archaeology since the nineteenth century provided crucial tangible evidence through which to substantiate nationalist and colonialist discourses: from classical Greece and Pharaonic Egypt to Thai Siam, Vedic India and Jōmon Japan, archaeology worked hard in order to enable the modern states in possession of ancient relics to represent themselves as the inheritors of a tradition symbolised in those relics, and at the same time pose as the guardians of that tradition. As it happens, such traditions were promoted as of not just local significance, but of a much wider, even global importance. However, as in the last 20 years archaeology has become, under the influence of poststructuralist semiotics, social theory and anthropology, a less "exact science", it may be seen to have acquired a rather subversive tone, working against the hegemonic narratives deployed in order to give the past its "historical" meaning. This has enabled counterhegemonic discourses, by way of indigenous, peripheral or alternative attempts to "decolonise" practices, interpretations and even theories. In recent years, these seem to thrive both in the old colonial world as well as in nominally independent "cryptocolonies" in the periphery of the west, frustrated with the political, financial, cultural oppression of an often imagined metropolis. ${ }^{27}$ Such postcolonial archaeologies take advantage of crossdisciplinary discussions of individual and collective memory, social and cultural identities, and the technologies of feeling and perception in order to "move towards new futures in which emotions of belonging can be strongly and proudly felt at a local level, but also effectively mobilised at more global levels to gain recognition and the resources necessary for local cultural forms to thrive". ${ }^{28}$

A widespread trend towards the musealisation of the present through the preservation of the past is therefore in process, and has been for quite some time. Mass consumption of the past as a collec- 
tive cultural resource acquires the form of nostalgia, a nostalgia however strongly referring to the present, thus rendering it as a time already experienced, "lived". ${ }^{29}$ This marked a shift from "history" - largely left to the "experts" in the academia and state-controlled research centres - to "heritage", everybody's business that is. The shift from history to heritage, from the certainty that the past is controlled by an academic discipline to the possibility that it might, instead, be shared as a collective experience, has marked a new, grassroots approach to culture and its management, as well as new ways of managing cultural economics: the spread of tourist consumerism, the adoption of new leisure lifestyles and the globalisation of pleasure and learning meant that local cultures were renegotiated at large and that new opportunities for cultural distinction were presenting themselves. With memory fast becoming spectacle and commodity, ${ }^{30}$ and culture under the, real or imaginary, threat of "Disneyfication", ${ }^{31}$ archaeology has been forced, at long last, to abandon its rigid Enlightened self, embrace its fears of epistemological fragmentation and ultimately welcome theoretical diversity.

\section{Yes, but is this archaeology?}

Needless to say, an essentialist's account of this topic would have been much different (if at all; think of the "classical archaeologist" in figs 1 and 2). As a graduate at Oxford in the early 1990s, I remember many of my seniors - and a few of my teachers - scoffing at archaeological theorists elsewhere "showing nothing but charts and graphs to their pupils" and the furore caused when, in May 1992, the University of Cambridge decided to confer one of its prestigious honorary degrees on Derrida. Such self-assured arrogance as displayed by those Oxford dons mirrored western thought's confidence of its intellectual genealogy which was thought to underline its superiority over the "irrationalism" of others, far and near. It was precisely that kind of dogmatic thinking that led to the conviction that history had ended just when in fact it was about to recharge with a vengeance. As history was now developing in centrifugal orbits, new archaeologies emerged - they still do - as ways to decolonise, reimagine or even reinvent that much coveted commodity we call the past. And as archaeology was gradually abandoning the kind of monolithic western cultural logic it had so dutifully served since the nineteenth century, fragmentation was perhaps inevitable. One could also argue that, owing to our field's relentless bombardment by innumerable trends, ideas and schools of thought, we all may be experiencing persistent symptoms of theory fatigue. (A simple count of all the "-isms" or the "-ities" necessary to compile a decent handbook of archaeology these days - or write a piece such as this essay for that matter - would suffice to uphold my point ${ }^{32}$ )

So, many would answer my question with a vociferous "no": to be honest, besides a handful of archaeological theorists mostly confined to a few archaeology departments here and there, archaeology as day-to-day practice anywhere in the world has been little, if at all, influenced by the developments outlined here. And when it was, that was mostly indirectly and usually reserved for matters practical or technical, such as the use of information technology, digital archival systems and statistics. Empirical positivism, the fetishist conviction that what we do is all about raw data and "facts", and the naiive reassurance that common sense and a good library is all a decent archaeologist really needs, continue to rule archaeological thinking across the globe well into the twenty-first century. Inevitably, this has led to the marginalisation of the discipline, both as an academic and a social discourse, and 
its replacement by social anthropology and cultural studies. As a result, "archaeological" archaeology has rendered itself all but irrelevant in contemporary societies, be they western or not. What this has taught us, however, is that intellectual complacency, epistemic self-confidence and academic elitism can be of little help to someone trying to make sense of the past, especially other people's. Since the days of Hodder's Reading the Past, archaeologists are beginning to realise that they are in fact internal to the problems they study: "archaeologists should wise-up and not expect to disconnect archaeological method, however scientific we want it to be, from everything that allows it to happen the way it does". ${ }^{33}$ Though many would still disagree, archaeology needs to think about multivocality and difference as much as interpreting contextual meanings, if not more so. In a sense, Indiana Jones was right: searching for the truth has nothing to do with archaeology.

\section{NOTES}

I am grateful to Antonis Liakos, who asked me to write this overview of archaeological theory in the last 20 years or so, and to the journal's two anonymous referees for their useful comments and suggestions.

1 Francis Fukuyama, “The End of History?", The National Interest, Summer 1989 (www.wesjones.com/ eoh.htm) accessed 16 May 2012.

2 Paul Bahn, Archaeology: A Very Short Introduction, Oxford: Oxford UP, 1996, 73.

3 Fukuyama, "The End of History?". For an archaeologist's take on the subject, see lan Morris, Why the West Rules - For Now, London: Profile Books, 2010.

4 Matthew Johnson, Archaeological Theory: An Introduction, Oxford: Blackwell, 1999, fig. 12.2.

5 Tony Bennett, The Birth of the Museum: History, Theory, Politics, London and New York: Routledge, 1995.

6 See, chiefly, Bruce G. Trigger, "Alternative Archaeologies: Nationalist, Colonialist, Imperialist", Man 19 (1984): 355-70; also Bruce G. Trigger, A History of Archaeological Thought, Cambridge: Cambridge UP, 1989, 27-72; 110-47; for a critique: Yannis Hamilakis, The Nation and its Ruins: Antiquity, Archaeology, and National Imagination in Greece, Oxford: Oxford UP, 2007, 19-21.

7 In many ways this is a process also observed in anthropology, see Johannes Fabian, Time and the Other. How Anthropology Makes its Object, New York: Columbia UP, 1983

8 Trigger, History of Archaeological Thought, 289-328; Johnson, Archaeological Theory, 12-33; 48-84.

9 David Clarke, “Archaeology: The Loss of Innocence”, Antiquity 47 (1973): 6-18.

10 Lewis R. Binford, “A Consideration of Archaeological Research Design”, American Antiquity 29 (1964): 425-41.

11 David L. Clarke, Analytical Archaeology, London: Methuen, 1968, 101-4.

12 Latest, considerably expanded and up-dated edition: lan Hodder and Scott Hutson, Reading the Past: Current Approaches to Interpretation in Archaeology, 3rd ed., Cambridge: Cambridge UP, 2003.

13 Ian Hodder, Reading the Past: Current Approaches to Interpretation in Archaeology, Cambridge: Cambridge UP, 1986, 77.

14 lan Hodder, Theory and Practice in Archaeology, London and New York: Routledge, 1992, 167. 
15 Hodder, Reading the Past, 146. Repeated almost verbatim in the edition of 2003, 204.

16 Ian Hodder, The Archaeological Process: An Introduction, Oxford: Blackwell, 1999, 154.

17 Though see lan Morris, "Classical Archaeology”, in John Bintliff (ed.), A Companion to Archaeology, Oxford: Blackwell, 2006, 253-71, claiming, with reference to the cartoon also discussed here, that "for better or for worse, classical archaeologists are staking out their own claims to be post-structuralist pseuds and phallocrat scum-bags". Though this may be true for many of us, I believe that it came as a result from osmosis with movements external rather than internal to archaeology as a self-contained discipline, which led to the further integration of the debate within the humanities and the social sciences at large.

18 Bjørnar Olsen, "Roland Barthes: From Sign to Text", in Christopher Tilley, Reading Material Culture, Oxford: Blackwell, 163-205.

19 See John Bintliff, "Time, Structure, and Agency: The Annales, Emergent Complexity, and Archaeology" in Bintliff, A Companion to Archaeology, 174-94.

20 Bruno Latour, Reassembling the Social. An Introduction to Actor-Network-Theory, Oxford: Oxford UP, 2005, 62-86 (emphasis in the original). And see Carl Knappett, An Archaeology of Interaction: Network Perspectives on Material Culture and Society, Oxford: Oxford UP, 2011, where networks are proposed as new analytical tool for archaeology.

21 Bruno Latour, We Have Never Been Modern, Cambridge MA: Harvard UP, 1993, 54 (1st pub. 1991).

22 Lynn Meskell, "Introduction: Object Orientations", in Lynn Meskell (ed.), Archaeologies of Materiality, Oxford: Blackwell, 2005, 1-17. See also Daniel Miller (ed.), Materiality, Durham and London: Duke UP, 2005 and Carl Knappett, "Materiality”, in lan Hodder (ed.), Archaeological Theory Today, 2nd ed., Cambridge: Polity, 2012, 188-207.

23 W.J.T. Mitchell, What Do Pictures Want? The Lives and Loves of Images, Chicago: University of Chicago Press, 2005.

24 Alfred Gell, Art and Agency: An Anthropological Theory, Oxford: Oxford UP, 1998.

25 See Bjørnar Olsen, "Symmetrical Archaeology”, in Hodder, Archaeological Theory Today, 208-28; also Bjørnar Olsen, In Defense of Things: Archaeology and the Ontology of Objects, Lanham: AltaMira Press, 2010.

26 John Boardman, The Archaeology of Nostalgia, London and New York: Thames \& Hudson, 2002, 7.

27 Michael Herzfeld, "The Absent Presence: Discourses of Crypto-colonialism”, The South Atlantic Quarterly 101 (2002): 899-926.

28 Chris Gosden, “Post-colonial Archaeology”, in Hodder, Archaeological Theory Today, 251-66.

29 Fredric Jameson, Postmodernism: Or, the Cultural Logic of Late Capitalism, Durham and London: Duke UP, 2003, 279-96.

30 Andreas Huyssen, Present Pasts: Urban Palimpsests and the Politics of Memory, Stanford: Stanford UP, 2003, 11-29.

31 Fredric Jameson, Archaeologies of the Future: The Desire Called Utopia and Other Science Fictions, London: Verso, 2007, 214-16.

32 The point is well taken by many of the contributions in John L. Bintliff and Mark Pearce, The Death of Archaeological Theory? Oxford: Oxbow Press, 2011.

33 Michael Shanks, "Archaeology and Politics", in Bintliff, Companion to Archaeology, 490-508. 